\title{
Hydrochemical Characteristics and Quality Assessment of Shallow Groundwater in the Xinzhou Basin, Shanxi, North China
}

\author{
Guanyin Shuai *(D), Jingli Shao *, Yali Cui, Qiulan Zhang and Yuntong Guo
}

check for updates

Citation: Shuai, G.; Shao, J.; Cui, Y.; Zhang, Q.; Guo, Y. Hydrochemical

Characteristics and Quality

Assessment of Shallow Groundwater in the Xinzhou Basin, Shanxi, North China. Water 2021, 13, 1993. https:// doi.org/10.3390/w13141993

Academic Editor: Per-Erik Mellander

Received: 4 June 2021

Accepted: 15 July 2021

Published: 20 July 2021

Publisher's Note: MDPI stays neutral with regard to jurisdictional claims in published maps and institutional affiliations.

Copyright: (C) 2021 by the authors Licensee MDPI, Basel, Switzerland. This article is an open access article distributed under the terms and conditions of the Creative Commons Attribution (CC BY) license (https:// creativecommons.org/licenses/by/ $4.0 /)$.
School of Water Resources and Environment, China University of Geosciences (Beijing), Beijing 100083, China; cuiyl@cugb.edu.cn (Y.C.); qlzhang919@cugb.edu.cn (Q.Z.); 3005170018@cugb.edu.cn (Y.G.)

* Correspondence: sgy2140@163.com (G.S.); jshao@cugb.edu.cn (J.S.)

Abstract: The hydrochemistry and quality of local shallow groundwater was assessed within the Xinzhou basin in Shanxi, North China. Piper diagrams, correlation analysis, principal component analysis, chloro-alkaline indices, ion proportion diagrams, and Gibbs diagrams were used to reveal the hydrochemical characteristics and evolution mechanisms of groundwater. Besides, two indicators of sodium adsorption ratio and soluble sodium percentage, USSL and Wilcox diagrams, and water quality index models were used to evaluate the groundwater quality for irrigation and drinking. In general, groundwater in most areas of the basin is fresh water with total dissolved solid lower than $1000 \mathrm{mg} / \mathrm{L}$. But there are salt water in some parts of the southern basin, with total dissolved solid higher than $1000 \mathrm{mg} / \mathrm{L}$, due to industrial and domestic pollution. The hydrochemical facies of groundwater in most areas are $\mathrm{HCO}_{3}-\mathrm{Ca}$ and mixed $\mathrm{HCO}_{3}-\mathrm{Ca} \cdot \mathrm{Mg} \cdot \mathrm{Na}$ types, while it is $\mathrm{HCO}_{3} \cdot \mathrm{SO}_{4} \cdot \mathrm{Cl}-\mathrm{Na}$ type in a small part of the basin. Nitrate pollution widely occurred in the basin because of the use of nitrogenous fertilizers. The dominant mechanism controlling the evolution of groundwater chemistry compositions was the weathering of rock minerals. It mainly reflected in the dissolution of carbonate minerals. And the carbonate dissolution is the major origins of $\mathrm{HCO}_{3}{ }^{-}$, $\mathrm{Ca}^{2+}$, and $\mathrm{Mg}^{2+}$ in groundwater. However, Na-Ca exchange is the important source of $\mathrm{Na}^{+}$. Shallow groundwater was suitable for irrigation and drinking except for some southern parts of the basin. These results will be helpful for the protection and efficient management of groundwater in the Xinzhou basin.

Keywords: hydrochemical characteristics; sources of main ions; groundwater evolution; nitrate pollution; water quality assessment

\section{Introduction}

More than one third of the area in China has an arid to semi-arid climate and most of this is located in the north of the country. Groundwater is the most important water resources and widely used in those areas. Because it is more abundant than surface water; meanwhile, groundwater is extracted easily and its quality is generally better than the quality of surface water [1-5]. However, groundwater was increasingly affected in recent decades [6]. Moreover, regional groundwater pollution has become a very common problem in arid-semiarid areas with the growth of population and the development of industry and agriculture [7-9]. Therefore, it is necessary to investigate and acquaint the status, origin, and evolution of groundwater major ions in arid-semiarid areas, in order to solve current water environment problems and achieve the sustainable utilization of water resources. In addition, it is also important to evaluate groundwater quality for drinking and irrigation.

Many studies on the chemical characteristics and quality assessments of groundwater have been carried out [10-13]. Li Peiyue evaluated the status and evolution of groundwater 
compositions in two coalfields, and found that natural factors, like geological and hydrogeological conditions, as well as human activities had a combined effect on groundwater compositions, which can lead to the difference of groundwater chemistry characteristics in different areas [11,14]. Su Zhenmin investigated chemical characteristics of groundwater in Yinchuan area, and proved that surface water seepage, other aquifers leakage, and hydrogeological processes such as mineral dissolution and their speed of dissolution, as well as ion exchange played an important role in controlling the chemical evolution of groundwater [15-17]. However, when one or more kinds of groundwater chemistry compositions exceed their standard limits, it means groundwater pollution occurs. Moreover, groundwater pollution has a great impact on life and production. Therefore, various methods have been developed to assess the potential risks of groundwater pollution to human health and ecological safety. Tian Hui employed the water quality index model $(W Q I)$ widely used over the world to assess the suitability of groundwater for drinking purposes in the Hailun area, and then got the spatial distribution of the water quality index based on the evaluated results [2]. Li Peiyue used three indicators, which were sodium adsorption ratio (SAR), soluble sodium percentage $(\% \mathrm{Na})$, and residual sodium carbonate (RSC), to assess irrigation water quality in a mining area, and found local groundwater was suitable for agricultural purposes [11].

The Xinzhou basin, located in a typical arid-semiarid region, is an important agricultural district where the area of cultivated land accounts for about $75 \%$. It also distributes scattered coal mines and gold mines. The life of local residents, agricultural irrigation, and industrial production rely heavily on groundwater due to the shortage of surface water. Thus, it is vital to ensure the safety of local groundwater resources. Han Dongmei studied hydrochemical characteristics in some small areas of the Xinzhou basin, including the Yangwu river alluvial fan, the Daying and Qicun geothermal system. And her study revealed that groundwater chemistry was dominated by water-rock interaction; mixing between thermal and non-thermal groundwater can change the chemical compositions of groundwater [18-20]. Sun Jing and Zhang Xiaolun also discussed the hydrochemical characteristics of local geothermal fields [21,22]. While previous research has focused on the hydrochemical characteristics and evolution of small areas within the Xinzhou basin, this and groundwater quality status has to our knowledge not been studied within the whole basin. Therefore, this paper focuses on the groundwater of the whole basin and the following research is done: (1) describing the hydrochemical characteristics of shallow groundwater in the whole basin, including the concentrations of various ions, the status of ions exceeding their standard limits, and hydrochemical types; (2) analyzing the origin of main ions and the reason of nitrate pollution; (3) discussing the evolution mechanisms of groundwater chemistry in the basin; (4) evaluating the quality of local shallow groundwater; (5) proposing suggestions for pollution control.

\section{Study Area}

The Xinzhou basin is located in the middle-northern part of Shanxi province between latitudes $38^{\circ} 12^{\prime}-39^{\circ} 27^{\prime} \mathrm{N}$ and longitudes $112^{\circ} 13^{\prime}-113^{\circ} 57^{\prime} \mathrm{E}$, covering an area of $3385.2 \mathrm{~km}^{2}$ (Figure 1). It is in the arid-semiarid area of north China with annual average evaporation of about $1600 \mathrm{~mm}$ and annual precipitation of $418 \mathrm{~mm}$ [19]. Hutuo River is the largest river in the basin and flows through the whole basin. Its main tributaries include Yunzhong River, Muma River, and Yangwu River, etc. 


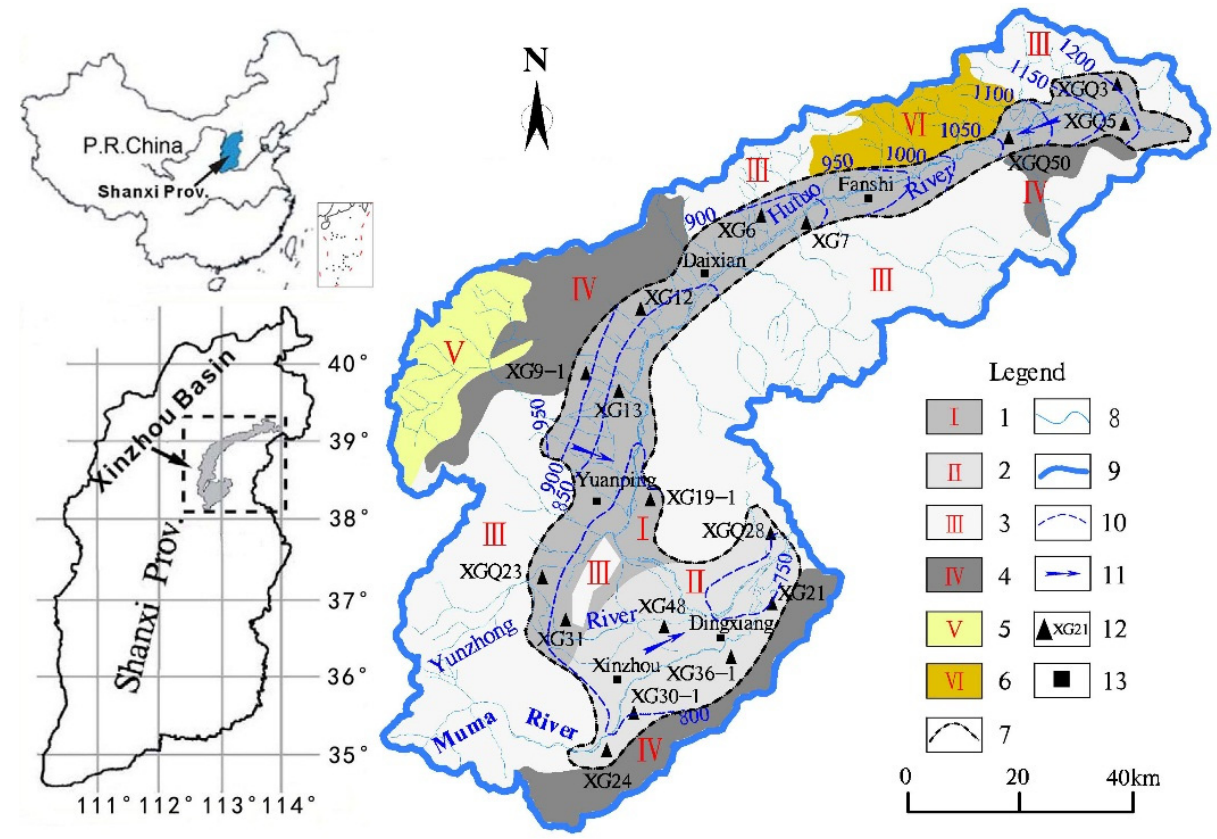

Figure 1. Hydrogeological map and monitoring well locations of the study area. 1. Quaternary alluvial proluvial sediment; 2. Quaternary alluvial lacustrine sediment; 3. Magmatic and metamorphic rock; 4. Limestone; 5 . Detrital rock; 6. Basalt; 7. Basin boundary; 8. River; 9. Basin watershed; 10. Contours of groundwater level; 11. Groundwater flow direction; 12. Monitoring well locations; 13. County.

The basin topography is a " 6 " shaped depression surrounded by mountains. And the elevation in the north of the basin is higher than that in the south. The geomorphic types from the basin watershed to the basin center are high middle mountains, middle mountains, low middle mountains, hilly areas, alluvial proluvial inclined plains, and alluvial lacustrine plains. Among them, the alluvial proluvial inclined plain and the alluvial lacustrine plain are the main distribution areas of population, industry, and agriculture. And the boundary between these two plains is approximately the Yunzhong River. The former, a long strip shape area in a direction of $\mathrm{NE} 40^{\circ}-70^{\circ}$, is located in the north of the Yunzhong River, mainly composed of quaternary alluvial proluvial sediments. The latter is located in the southeast of the Yunzhong River, and mainly composed of quaternary alluvial lacustrine sediments (Figure 1).

The strata outcropping in the study area include magmatic and metamorphic rocks of Archean age, Cambrian-ordovician dolomite and limestone, Carboniferous-Jurassic layered sandstone and shales, Tertiary basalt, and various Holocene and late Pleistocene sediments. These sediments contain alluvial and lacustrine sand, sandy loam, silt, and silty clay. The strata below the Cenozoic sediments in the basin are mostly the Archean igneous and metamorphic rocks, and locally Cambrian limestone. Cenozoic sediments range between 50 and $2100 \mathrm{~m}$ thickness including about 50 to $360 \mathrm{~m}$ of Quaternary sediments [19].

The Quaternary sediments in the plain constitute the shallow aquifer of pore water. The thickness of this aquifer is over $130 \mathrm{~m}$. Hutuo River is its surface watershed. The main recharge sources of this aquifer are lateral influx of groundwater from mountain areas, as well as precipitation and irrigation water infiltration. Controlled by topography, the shallow groundwater flows mainly from the piedmont on both sides of the basin to the Hutuo River valley and from the upper reaches of the Hutuo River to the lower reaches (Figure 1). The main discharge patterns include groundwater pumping, lateral outflow, and evapotranspiration. 


\section{Materials and Methods}

\subsection{Sample Data Collecting and Reliability Checking}

A total of seventeen monitoring wells of shallow groundwater were chosen (Figure 1). The monitoring wells are evenly distributed in the whole basin. We took one groundwater sample from each monitoring well in May 2019. This study discussed the hydrochemical characteristics of shallow groundwater and its quality in the study area based on the analysis of fourteen kinds of indicators with larger values, including $\mathrm{pH}$, total dissolved solids (TDS), total hardness (TH), permanganate index $\left(\mathrm{COD}_{\mathrm{Mn}}\right), \mathrm{HCO}_{3}{ }^{-}, \mathrm{SO}_{4}{ }^{2-}, \mathrm{Cl}^{-}, \mathrm{F}^{-}$, $\mathrm{Ca}^{2+}, \mathrm{Mg}^{2+}, \mathrm{Na}^{+}, \mathrm{K}^{+}$, and nitrogen compounds $\left(\mathrm{NO}_{3}{ }^{-}\right.$and $\left.\mathrm{NO}_{2}{ }^{-}\right)$. However, $\mathrm{CO}_{3}{ }^{2-}, \mathrm{Fe}^{3+}$, $\mathrm{Fe}^{2+}, \mathrm{NH}_{4}{ }^{+}$, and $\mathrm{Mn}^{2+}$ were not analyzed, because the content of them in all samples was very low.

The ion concentration data of each sample were checked for accurately using the method of calculating percent charge balance errors (\%CBE) [6]. The formula is shown below:

$$
\% \mathrm{CBE}=\frac{\sum \text { cations }-\sum \text { anions }}{\sum \text { cations }+\sum \text { anions }} \times 100 \%
$$

where all ions are expressed in meq/L. The relative errors (\%CBE) of all samples after calculation were less than $3 \%$, which proved the reliability of the data. Therefore, all data were used for analysis. The indicators of all samples are listed in Table 1.

Table 1. General information of samples.

\begin{tabular}{|c|c|c|c|c|c|c|c|c|c|c|c|c|c|c|}
\hline ID & $\mathrm{pH}$ & TDS & TH & $\mathrm{COD}_{\mathrm{Mn}}$ & $\mathrm{Ca}^{2+}$ & $\mathrm{Mg}^{2+}$ & $\mathrm{Na}^{+}$ & $\mathbf{K}^{+}$ & $\mathrm{HCO}_{3}{ }^{-}$ & $\mathrm{SO}_{4}{ }^{2-}$ & $\mathrm{Cl}^{-}$ & $\mathrm{NO}_{3}{ }^{-}$ & $\mathrm{NO}_{2}{ }^{-}$ & $\mathbf{F}^{-}$ \\
\hline XGQ3 & 7.87 & 264 & 149 & 0.93 & 39.89 & 11.00 & 37.78 & 1.24 & 252.42 & 10.16 & 4.79 & 17.88 & 0.01 & 0.42 \\
\hline XGQ5 & 8.05 & 356 & 276 & 0.88 & 59.84 & 29.69 & 13.92 & 1.01 & 233.19 & 10.01 & 28.75 & 81.95 & 0.03 & 0.44 \\
\hline XG6 & 8.12 & 324 & 190 & 0.93 & 36.26 & 23.09 & 51.28 & 0.79 & 299.82 & 10.36 & 20.54 & 16.50 & 0.03 & 0.70 \\
\hline XGQ7 & 7.95 & 394 & 290 & 1.21 & 74.34 & 24.19 & 22.02 & 3.28 & 240.60 & 113.32 & 10.95 & 10.17 & 0.02 & 0.22 \\
\hline XG9-1 & 8.05 & 221 & 190 & 0.93 & 47.14 & 16.49 & 6.02 & 1.01 & 229.10 & 9.22 & 4.11 & 7.90 & 0.02 & 0.12 \\
\hline XG12 & 7.83 & 478 & 367 & 1.02 & 54.40 & 54.98 & 36.86 & 1.01 & 437.88 & 9.46 & 41.07 & 23.12 & 0.01 & 0.22 \\
\hline XG13 & 7.48 & 261 & 226 & 1.35 & 59.84 & 17.59 & 6.49 & 1.01 & 244.30 & 9.13 & 9.58 & 22.14 & 0.05 & 0.22 \\
\hline XG19-1 & 8.02 & 340 & 226 & 0.93 & 43.52 & 27.49 & 37.63 & 0.79 & 288.71 & 20.21 & 17.80 & 28.02 & 0.00 & 0.72 \\
\hline XG21 & 8.12 & 1706 & 471 & 1.51 & 56.21 & 79.17 & 453.14 & 4.67 & 706.98 & 388.02 & 312.15 & 43.36 & 0.03 & 1.52 \\
\hline XGQ23 & 8.05 & 473 & 331 & 0.83 & 74.34 & 34.09 & 30.88 & 0.57 & 262.80 & 63.12 & 27.38 & 95.92 & 0.06 & 0.70 \\
\hline XG24 & 7.94 & 297 & 181 & 2.12 & 47.14 & 14.29 & 39.20 & 0.57 & 259.10 & 29.12 & 8.21 & 11.88 & 0.01 & 0.76 \\
\hline XGQ28 & 7.65 & 227 & 172 & 1.23 & 56.21 & 6.60 & 11.74 & 2.37 & 185.07 & 25.64 & 8.21 & 8.84 & 0.01 & 0.68 \\
\hline XG30-1 & 8.15 & 271 & 199 & 0.83 & 41.70 & 21.99 & 22.02 & 1.01 & 255.01 & 9.21 & 7.53 & 21.15 & 0.04 & 1.08 \\
\hline XG31 & 7.58 & 319 & 249 & 1.15 & 87.03 & 6.60 & 15.91 & 1.92 & 225.79 & 12.02 & 54.76 & 9.81 & 0.05 & 0.44 \\
\hline XG36-1 & 7.85 & 1743 & 602 & 1.02 & 56.21 & 111.06 & 372.01 & 5.60 & 644.06 & 357.10 & 175.24 & 333.19 & 0.11 & 1.52 \\
\hline XG48 & 8.15 & 364 & 217 & 0.85 & 63.46 & 13.20 & 52.64 & 2.37 & 322.03 & 13.16 & 32.86 & 8.11 & 0.01 & 1.12 \\
\hline XGQ50 & 7.71 & 356 & 285 & 1.03 & 61.65 & 30.79 & 17.08 & 1.01 & 329.43 & 10.36 & 16.43 & 33.90 & 0.03 & 0.68 \\
\hline
\end{tabular}

Units: $\mathrm{mg} / \mathrm{L}$ except $\mathrm{pH}$. Total coliform (MPN/100 mL) was not detected in all samples.

\subsection{Analysis Methods and Procedures}

Statistical analysis methods were used to analyze the values of fourteen indicators, which can get a preliminary understanding of the groundwater quality of the study area. Piper and Gibbs diagrams were constructed to reveal groundwater types and its chemistry evolution mechanisms. Correlation analysis and principal component analysis (PCA) were used to find the correlation between indicators and the hydrochemical processes in groundwater system. And then, combined with some other hydrochemical methods, like ion proportion diagrams and chloro-alkaline indices etc., the sources of major ions can be further determined. Besides, $\mathrm{NO}_{3}{ }^{-}$was the most widely distributed ion exceeding its standard limit. The reason and process of its appearance were analyzed combined with the status of agricultural development in Xinzhou basin. Finally, two indicators of sodium adsorption ratio (SAR) and soluble sodium percentage (\%Na), as well as USSL and Wilcox diagrams were used to evaluate irrigation water quality. Meanwhile, the water quality index model (WQI) was employed to assess drinking water quality. Most of analysis processes were performed using statistical analysis software SPSS (version 17.0) and water chemical analysis software Aq.QA (version 1.1). Among them, the software 
of SPSS was used for statistical analysis, correlation analysis, and principal component analysis. And the software of Aq.QA was used to draw piper diagrams to analyze the chemical characteristics of samples.

\subsection{Methods of Water Quality Assessment}

\subsubsection{Indicators of SAR and $\% \mathrm{Na}$}

In general, irrigation water with high sodium content will affect the growth of crops. Thus, commonly using two indicators of SAR and \%Na assesses sodium hazards [23]. These two indicators can be calculated by:

$$
\begin{gathered}
\mathrm{SAR}=\frac{\mathrm{Na}^{+}}{\sqrt{\frac{\mathrm{Ca}^{2+}+\mathrm{Mg}^{2+}}{2}}} \\
\% \mathrm{Na}=\frac{\mathrm{Na}^{+}}{\mathrm{Na}^{+}+\mathrm{K}^{+}+\mathrm{Ca}^{2+}+\mathrm{Mg}^{2+}} \times 100
\end{gathered}
$$

where the unit of all ions is meq/L.

\subsubsection{Drinking Water Quality Index Model}

The WQI model, originally proposed by Brown in 1970, is a simple method to determine the suitability of groundwater for drinking purposes [2]. This method assesses the quality of groundwater by converting the content of all kinds of ions into a simple value [13]. It can be applied based on $\mathrm{pH}$, TDS, TH, $\mathrm{COD}_{\mathrm{Mn}}, \mathrm{Ca}^{2+}, \mathrm{Mg}^{2+}, \mathrm{Na}^{+}, \mathrm{K}^{+}, \mathrm{HCO}_{3}{ }^{-}, \mathrm{SO}_{4}{ }^{2-}$, $\mathrm{Cl}^{-}, \mathrm{NO}_{3}{ }^{-}, \mathrm{NO}_{2}{ }^{-}$, and $\mathrm{F}^{-}$. The weight of each ion shown in Table 2 was assigned by its relative importance to health of human referring to WHO standards [24]. The application of the model consists of four steps.

Table 2. Weight $\left(w_{i}\right)$ and relative weight $\left(W_{i}\right)$ of each indicator.

\begin{tabular}{ccccc}
\hline Ions & Units & Weight $\left(w_{\boldsymbol{i}}\right)$ & Relative Weight $\left(\boldsymbol{W}_{\boldsymbol{i}}\right)$ & WHO Standards $\mathbf{1}^{\mathbf{1}}$ \\
\hline $\mathrm{pH}$ & - & 2 & 0.038 & $6.5-8.5$ \\
$\mathrm{TDS}$ & $\mathrm{mg} / \mathrm{L}$ & 4 & 0.077 & 1000 \\
$\mathrm{TH}$ & $\mathrm{mg} / \mathrm{L}$ & 4 & 0.077 & 500 \\
$\mathrm{COD}_{\mathrm{Mn}}$ & $\mathrm{mg} / \mathrm{L}$ & 5 & 0.096 & 10 \\
$\mathrm{Ca}^{2+}$ & $\mathrm{mg} / \mathrm{L}$ & 3 & 0.058 & 300 \\
$\mathrm{Mg}^{2+}$ & $\mathrm{mg} / \mathrm{L}$ & 5 & 0.096 & 30 \\
$\mathrm{Na}^{+}$ & $\mathrm{mg} / \mathrm{L}$ & 4 & 0.077 & 200 \\
$\mathrm{~K}^{+}$ & $\mathrm{mg} / \mathrm{L}$ & 2 & 0.038 & 12 \\
$\mathrm{HCO}_{3}{ }^{-}$ & $\mathrm{mg} / \mathrm{L}$ & 1 & 0.019 & 500 \\
$\mathrm{SO}_{4}{ }^{-}$ & $\mathrm{mg} / \mathrm{L}$ & 3 & 0.058 & 250 \\
$\mathrm{Cl}^{-}$ & $\mathrm{mg} / \mathrm{L}$ & 4 & 0.077 & 250 \\
$\mathrm{NO}_{3}{ }^{-}$ & $\mathrm{mg} / \mathrm{L}$ & 5 & 0.096 & 50 \\
$\mathrm{NO}_{2}{ }^{-}$ & $\mathrm{mg} / \mathrm{L}$ & 5 & 0.096 & 3 \\
$\mathrm{~F}^{-}$ & $\mathrm{mg} / \mathrm{L}$ & 5 & 0.096 & 1.5 \\
$\mathrm{Sum}^{-}$ & - & 52 & 1 & - \\
\hline
\end{tabular}

${ }^{1}$ WHO standards refer to the fourth edition of Guidelines for Drinking Water Quality [25].

Step one: calculating relative weight $\left(W_{i}\right)$ according to Equation (4).

$$
W_{i}=\frac{w_{i}}{\sum_{i=1}^{n} w_{i}}
$$

where $W_{\mathrm{i}}, w_{i}, n$ represent the relative weight of each indicator, the weight of each indicator, and the number of indicators, respectively. The results are shown in Table 2.

Step two: calculating quality rating $\left(q_{i}\right)$ according to Equation (5).

$$
q_{i}=\frac{C_{i}}{S_{i}} \times 100
$$


where $C_{i}, S_{i}$, and $q_{i}$ represent the value of each indicator, the corresponding WHO standard value of this indicator, and the rating based on the value of this indicator, respectively.

Step three: calculating the sub-index (SI) according to Equation (6).

$$
S I_{i}=W_{i} \times q_{i}
$$

Step four: calculating the WQI of each groundwater sample according to Equation (7).

$$
W Q I=\sum_{i=1}^{n} S I_{i}
$$

The classification standard of water quality for drinking based on WQI is shown in Table 3 [13].

Table 3. Water quality classification for drinking.

\begin{tabular}{cc}
\hline WQI Level & Water Quality \\
\hline$<26$ & Excellent quality \\
$26-50$ & Good quality \\
$51-75$ & Poor quality \\
$76-100$ & Very poor quality \\
$>100$ & Unsuitable for any use \\
\hline
\end{tabular}

\section{Results and Discussion}

\subsection{Hydrochemical Characteristics}

The statistics of groundwater compositions in the study area are shown in Table 4. From it, groundwater in this area was generally weakly alkaline with $\mathrm{pH}$ ranging from 7.48 to 8.15 . And total coliform (MPN/100 mL) was not detected in all samples. Compared with class III groundwater in the China's quality standard of groundwater [26], the values of $\mathrm{COD}_{\mathrm{Mn}}$ and $\mathrm{NO}_{2}{ }^{-}$in all samples were within acceptable ranges. However, the values of TDS, $\mathrm{TH}, \mathrm{Na}^{+}, \mathrm{SO}_{4}{ }^{2-}, \mathrm{Cl}^{-}, \mathrm{F}^{-}$, and $\mathrm{NO}_{3}{ }^{-}$in some samples exceeded their standard limits and maximum exceeding multiples were 1.7, 1.3, 2.3, 1.6, 1.2, 1.5, and 16.7 times, respectively. The values of TDS, $\mathrm{TH}, \mathrm{Na}^{+}$, and $\mathrm{SO}_{4}{ }^{2-}$ exceeding their standard limits were concentrated in two samples from wells XG21 and XG36-1, accounting for $11.8 \%$ of seventeen wells. Those two wells are located near Dingxiang county in the south of the basin where processing and manufacturing industry is relatively developed, and the number of local migrant workers is large. The concentrations of $\mathrm{Cl}^{-}$and $\mathrm{F}^{-}$exceeding their standard limits both occurred in the sample from well XG21. Besides, the concentration of $\mathrm{F}^{-}$beyond its standard limit was also observed in the samples from wells XG30-1, XG36-1, and XG48. Thus, the samples with the abnormal $\mathrm{Cl}^{-}$and $\mathrm{F}^{-}$accounted for $5.9 \%$ and $23.5 \%$, respectively. Moreover, the wells XG30-1 and XG48 are also distributed in the south of the basin. The concentration of $\mathrm{NO}_{3}{ }^{-}$exceeding its standard limit occurred in nine samples from wells XGQ5, XG12, XG13, XG19-1, XG21, XGQ23, XG30-1, XG36-1, and XGQ50, accounting for more than $50 \%$. And those wells are evenly distributed in the whole basin. Main cation order was $\mathrm{Na}^{+}>\mathrm{Ca}^{2+}>\mathrm{Mg}^{2+}>\mathrm{K}^{+}$, and main anion order was $\mathrm{HCO}_{3}{ }^{-}>\mathrm{SO}_{4}{ }^{2-}>\mathrm{Cl}^{-}>\mathrm{NO}_{3}{ }^{-}$, based on the average concentration of each ion.

The Piper diagram is a common method to study hydrochemical types by describing the content of major ions. A Piper diagram is shown in Figure 2. The lower left deltashaped region is the distribution position of cations. From it, samples were mainly plotted in the zones of A and B, suggesting that the majority of samples are calcium-type and mixed-type water. Only two samples from wells XG21 and XG36-1 were located in the zone $\mathrm{D}$ which represents the area of sodium-type water. The lower right delta-shaped region is the distribution position of anions. From it, most samples were plotted in the zone E, suggesting the dominance of bicarbonate-type water. The samples from the wells XG21 and XG36-1 were still different from others as before. They were mixed-type water in which 
the milligram equivalent percentages of $\mathrm{HCO}_{3}{ }^{-}, \mathrm{SO}_{4}{ }^{2-}$, and $\mathrm{Cl}^{-}$were all beyond $20 \%$. The intermediate rhombus reflects the overall hydrochemical characteristics of samples. From it, most samples were located in the zones of 1,3, and 5, which means alkaline earth exceeding alkalies, weak acids exceeding strong acids, and carbonate hardness exceeding $50 \%$, respectively. However, those two abnormal samples were predominated by alkalies and strong acids. The chemical facies of the shallow groundwater were $\mathrm{HCO}_{3}-\mathrm{Ca}$ and mixed $\mathrm{HCO}_{3}-\mathrm{Ca} \cdot \mathrm{Mg} \cdot \mathrm{Na}$ types in most areas of the basin, while $\mathrm{HCO}_{3} \cdot \mathrm{SO}_{4} \cdot \mathrm{Cl}-\mathrm{Na}$ type in the small parts of the southern basin, according to the above analysis.

Table 4. Statistical summary of indicators.

\begin{tabular}{ccccc}
\hline Parameters & Max & Min & Mean & National Standard \\
\hline $\mathrm{pH}$ & 8.15 & 7.48 & 7.92 & $6.5-8.5$ \\
$\mathrm{TDS}$ & 1743 & 221 & 493.76 & 1000 \\
$\mathrm{TH}$ & 602.17 & 149.41 & 271.92 & 450 \\
$\mathrm{CO}_{\mathrm{Mn}}$ & 2.12 & 0.83 & 1.1 & 3 \\
$\mathrm{Ca}^{2+}$ & 87.03 & 36.26 & 56.42 & - \\
$\mathrm{Mg}^{2+}$ & 111.06 & 6.60 & 30.72 & 200 \\
$\mathrm{Na}^{+}$ & 453.14 & 6.02 & 72.15 & - \\
$\mathrm{K}^{+}$ & 5.6 & 0.57 & 1.78 & - \\
$\mathrm{HCO}_{3}^{-}$ & 706.98 & 185.07 & 318.61 & 250 \\
$\mathrm{SO}^{2-}$ & 388.02 & 9.13 & 64.68 & 250 \\
$\mathrm{Cl}^{-}$ & 312.15 & 4.11 & 45.9 & 20 \\
$\mathrm{NO}_{3}^{-}$ & 333.19 & 7.90 & 45.52 & 1 \\
$\mathrm{NO}_{2}^{-}$ & 0.11 & 0.004 & 0.029 & 1 \\
$\mathrm{~F}^{-}$ & 1.52 & 0.12 & 0.68 & \\
\hline
\end{tabular}

Units: $\mathrm{mg} / \mathrm{L}$ except $\mathrm{pH}$.

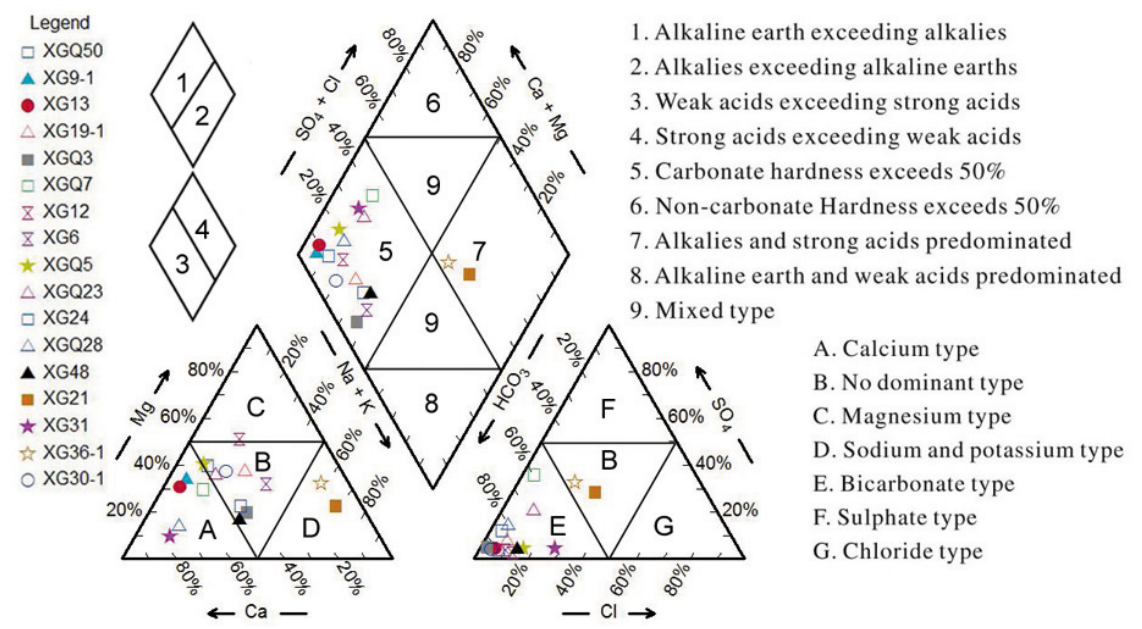

Figure 2. Piper diagram of groundwater samples.

\subsection{Correlation of Indicators}

The hydrochemical evolution had a great distinction between the areas near the wells XG21 and XG36-1 and other areas, because the areas near those two wells were seriously influenced by human activities. Therefore, only the data of fifteen samples from the other wells were used for discussion. The correlation coefficients between hydrochemical indicators are shown in Table 5. It should be noted that a correlation coefficient shows the closeness between two indicators. And the absolute value of a correlation coefficient exceeding 0.7 , ranging from 0.4 to 0.7 , or being less than 0.4 means a strong correlation, an ordinary correlation, or a weak correlation, respectively. Besides, the following explanation to Table 5 was based on the significance level of 0.01 . 
Table 5. Pearson correlation coefficients of indicators.

\begin{tabular}{|c|c|c|c|c|c|c|c|c|c|c|c|c|c|c|}
\hline & $\mathrm{pH}$ & TDS & TH & $\operatorname{COD}_{M n}$ & $\mathrm{Ca}^{2+}$ & $\mathrm{Mg}^{2+}$ & $\mathrm{Na}^{+}$ & $\mathbf{K}^{+}$ & $\mathrm{HCO}_{3}{ }^{-}$ & $\mathrm{SO}_{4}^{2-}$ & $\mathrm{Cl}^{-}$ & $\mathrm{NO}_{3}{ }^{-}$ & $\mathrm{NO}_{2}{ }^{-}$ & $\mathbf{F}^{-}$ \\
\hline $\mathrm{pH}$ & 1 & & & & & & & & & & & & & \\
\hline TDS & 0.211 & 1 & & & & & & & & & & & & \\
\hline $\mathrm{TH}$ & -0.061 & $0.885^{* *}$ & 1 & & & & & & & & & & & \\
\hline $\mathrm{COD}_{\mathrm{Mn}}$ & -0.374 & -0.221 & -0.216 & 1 & & & & & & & & & & \\
\hline $\mathrm{Ca}^{2+}$ & -0.395 & 0.418 & 0.558 * & 0.02 & 1 & & & & & & & & & \\
\hline $\mathrm{Mg}^{2+}$ & 0.203 & $0.773^{* *}$ & $0.814^{* *}$ & -0.274 & -0.028 & 1 & & & & & & & & \\
\hline $\mathrm{Na}^{+}$ & $0.532 *$ & 0.389 & -0.056 & -0.048 & -0.327 & 0.162 & 1 & & & & & & & \\
\hline $\mathrm{K}^{+}$ & -0.159 & -0.025 & -0.01 & -0.02 & 0.486 & -0.352 & -0.109 & 1 & & & & & & \\
\hline $\mathrm{HCO}_{3}{ }^{-}$ & 0.15 & $0.645^{* *}$ & $0.544^{*}$ & -0.176 & -0.142 & $0.755^{* *}$ & $0.535 *$ & -0.248 & 1 & & & & & \\
\hline $\mathrm{SO}_{4}{ }^{2-}$ & 0.118 & 0.395 & 0.333 & 0.152 & 0.446 & 0.088 & -0.01 & $0.515 *$ & -0.204 & 1 & & & & \\
\hline $\mathrm{Cl}^{-}$ & -0.113 & 0.590 * & $0.573^{*}$ & -0.223 & $0.591 *$ & 0.276 & 0.194 & 0.083 & 0.39 & -0.127 & 1 & & & \\
\hline $\mathrm{NO}_{3}{ }^{-}$ & 0.216 & $0.521 *$ & $0.526^{*}$ & -0.326 & 0.231 & 0.472 & -0.086 & -0.427 & 0.004 & 0.131 & 0.207 & 1 & & \\
\hline $\mathrm{NO}_{2}^{-}$ & -0.24 & 0.203 & 0.363 & -0.194 & 0.477 & 0.103 & -0.362 & -0.263 & -0.167 & 0.06 & 0.269 & 0.524 * & 1 & \\
\hline $\mathrm{F}^{-}$ & 0.441 & 0 & -0.267 & -0.094 & -0.188 & -0.19 & 0.502 & -0.072 & 0.055 & -0.164 & 0.011 & 0.037 & -0.075 & 1 \\
\hline
\end{tabular}

* Significantly correlated at the 0.05 level (two-tailed). ${ }^{* *}$ Significantly correlated at the 0.01 level (two-tailed). Principal Component Analysis.

From Table 5, TDS had a strong positive correlation with $\mathrm{Mg}^{2+}$ and an ordinary positive correlation with $\mathrm{HCO}_{3}{ }^{-}$, with correlation coefficients being 0.773 and 0.645 , respectively. TH also had a strong positive correlation with $\mathrm{Mg}^{2+}$ and the correlation coefficient between them was 0.814 . It suggests that the concentration change and space distribution of $\mathrm{Mg}^{2+}$ have a significant impact on TDS and TH. Besides, $\mathrm{HCO}_{3}{ }^{-}$also have a great influence on TDS.

$\mathrm{Mg}^{2+}$ had a strong positive correlation with $\mathrm{HCO}_{3}{ }^{-}$, with a correlation coefficient 0.775 , indicating the dissolution of the minerals containing $\mathrm{Mg}^{2+}$ and $\mathrm{CO}_{3}{ }^{2-} / \mathrm{HCO}_{3}{ }^{-}$, such as magnesite whose leading composition is $\mathrm{MgCO}_{3}$. The concentration of $\mathrm{Ca}^{2+}$ in most samples was the highest among all cations (Table 1), and the groundwater types in the basin were mainly $\mathrm{HCO}_{3}-\mathrm{Ca}$ and $\mathrm{HCO}_{3}-\mathrm{Ca} \cdot \mathrm{Mg} \cdot \mathrm{Na}$ types. Thus, it can be inferred that $\mathrm{Ca}^{2+}$ mostly originates from the dissolution of carbonate minerals. However, $\mathrm{Ca}^{2+}$ did not have an obvious correlation with $\mathrm{HCO}_{3}{ }^{-}$. The possible reasons are as follows. $\mathrm{HCO}_{3}{ }^{-}$has several sources including the dissolution of minerals containing $\mathrm{Ca}^{2+}$ and no $\mathrm{Ca}^{2+}$, such as calcite $\left(\mathrm{CaCO}_{3}\right)$, dolomite $\left(\mathrm{CaMg}\left(\mathrm{CO}_{3}\right)_{2}\right)$, and magnesite $\left(\mathrm{MgCO}_{3}\right)$. Meanwhile, the adsorption capacity of rock and soil to $\mathrm{Ca}^{2+}$ is bigger than that to $\mathrm{Na}^{+}$, and the content of $\mathrm{Ca}^{2+}$ is higher than that of $\mathrm{Na}^{+}$in groundwater. Thus, Na-Ca exchange happens during groundwater flowing through the soil containing $\mathrm{Na}^{+}$, which results in $\mathrm{Ca}^{2+}$ leaving groundwater and $\mathrm{Na}^{+}$entering groundwater. Both of these factors together lead to the result that $\mathrm{Ca}^{2+}$ had few correlations with $\mathrm{HCO}_{3}{ }^{-}$. This may also illustrate that $\mathrm{Na}-\mathrm{Ca}$ exchange is an important source of $\mathrm{Na}^{+}$in groundwater. $\mathrm{NO}_{3}{ }^{-}$and $\mathrm{NO}_{2}{ }^{-}$also had a certain relevance. It will be explained later.

It should be noted that chemical reactions in a groundwater system are complex. So the correlation analysis, though useful, can only provide a rough insight to water-rock reactions.

\subsection{Principal Component Analysis}

The method of PCA evaluates associated constituent loadings and then determines principle components (PCs), based on the correlations between indicators [27]. This research used the data from fifteen samples to extract PCs and Table 6 shows the total variance explained of each PC and the loading of PCs. From it, five PCs with their eigenvalues more than one were selected, accounting for $85 \%$ of the total variance. Among them, PC1 and PC2, which explained $30.6 \%$ and $21 \%$ of the variance respectively, accounted for more than $50 \%$. And other three PCs explained $13.4 \%, 10.9 \%$, and $9.2 \%$ of the variance, respectively. 
Table 6. Total variance explained of each PC and loadings of PCs.

\begin{tabular}{cccccc}
\hline \multirow{2}{*}{ Indicators } & \multicolumn{5}{c}{ Components } \\
\cline { 2 - 5 } & $\mathbf{P C 1}$ & $\mathbf{P C 2}$ & $\mathbf{P C 3}$ & $\mathbf{P C 4}$ & PC5 \\
\hline $\mathrm{TDS}$ & $\underline{\mathbf{0 . 9 5 1}}$ & 0.072 & 0.253 & 0.024 & -0.067 \\
$\mathrm{TH}$ & $\underline{\mathbf{0 . 9 4 3}}$ & -0.232 & 0.041 & -0.133 & -0.117 \\
$\mathrm{Mg}^{2+}$ & $\underline{\mathbf{0 . 8 2 9}}$ & 0.266 & -0.125 & -0.262 & -0.339 \\
$\mathrm{HCO}_{3}{ }^{-}$ & $\underline{\mathbf{0 . 6 2 6}}$ & 0.522 & 0.145 & -0.500 & 0.079 \\
$\mathrm{NO}_{3}{ }^{-}$ & $\underline{\mathbf{0 . 6 2 2}}$ & -0.049 & -0.478 & 0.457 & -0.169 \\
$\mathrm{Ca}^{2+}$ & 0.439 & $-\mathbf{0 . 7 7 9}$ & 0.249 & 0.145 & 0.281 \\
$\mathrm{Na}^{+}$ & 0.194 & $\underline{\mathbf{0 . 7 4 5}}$ & 0.442 & 0.063 & 0.170 \\
$\mathrm{pH}^{-}$ & 0.137 & 0.676 & 0.151 & $\mathbf{0 . 5 4 9}$ & -0.215 \\
$\mathrm{~K}^{+}$ & -0.088 & 0.519 & 0.141 & $\mathbf{0 . 5 0 6}$ & 0.421 \\
$\mathrm{SO}_{4}{ }^{2-}$ & -0.149 & -0.463 & $\underline{\mathbf{0 . 7 7 3}}$ & 0.121 & 0.081 \\
$\mathrm{NO}_{2}{ }^{-}$ & 0.228 & -0.400 & $\underline{\mathbf{0 . 5 5 3}}$ & 0.358 & -0.545 \\
$\mathrm{COD}_{\text {Mn }}$ & 0.381 & -0.462 & -0.542 & 0.308 & 0.189 \\
$\mathrm{Cl}^{-}$ & -0.359 & -0.205 & 0.179 & -0.381 & -0.182 \\
Eigenvalue & 0.647 & -0.142 & 0.138 & -0.116 & $\underline{\mathbf{0 . 6 5 0}}$ \\
$\%$ of variance & 4.28 & 2.94 & 1.88 & 1.52 & 1.3 \\
Cumulative \% & 30.6 & 21 & 13.4 & 10.9 & 9.2 \\
\hline
\end{tabular}

Underlined and bold numbers are larger association parameters in each PC.

In $\mathrm{PC} 1, \mathrm{TDS}, \mathrm{TH}, \mathrm{Mg}^{2+}, \mathrm{HCO}_{3}{ }^{-}$, and $\mathrm{NO}_{3}{ }^{-}$had higher loadings. $\mathrm{Mg}^{2+}$ and $\mathrm{HCO}_{3}{ }^{-}$ originated from the dissolution of carbonate minerals according to the previous correlation analysis. For $\mathrm{NO}_{3}{ }^{-}$, it can be inferred that this ion in groundwater is mainly from the infiltration of nitrogenous substances with rainwater and irrigation water, because more than $70 \%$ of the Xinzhou basin is cultivated land where a large number of nitrogen fertilizers and potash fertilizers were used every year. This is also the reason why $\mathrm{NO}_{3}{ }^{-}$exceeding its standard limit occurred in more than half of the samples. For TDS and TH, these two indicators had larger loadings in PC1, due to the facts that the values of them mainly depend on high content ions; the content of $\mathrm{Mg}^{2+}$ and $\mathrm{HCO}_{3}{ }^{-}$in groundwater is high in the basin; both $\mathrm{Mg}^{2+}$ and $\mathrm{HCO}_{3}{ }^{-}$have higher loadings in PC1. Thus, $\mathrm{PC} 1$ mainly reflects the processes of carbonate mineral dissolution and human activity influences. In PC2, $\mathrm{Ca}^{2+}$ had a negative loading and $\mathrm{Na}^{+}$had a positive loading, suggesting $\mathrm{Na}-\mathrm{Ca}$ exchange happening. In addition, $\mathrm{Ca}^{2+}$ and $\mathrm{Na}^{+}$in groundwater also had high content. Therefore, PC1 and PC2 represent the processes that major ions with high content enter groundwater by water-rock interactions and human activities.

In $\mathrm{PC} 3, \mathrm{~K}^{+}$and $\mathrm{SO}_{4}{ }^{2-}$ had higher loadings. $\mathrm{K}_{2} \mathrm{SO}_{4}$ may be the main source of $\mathrm{K}^{+}$and $\mathrm{SO}_{4}{ }^{2-}$ in groundwater, because it is an important potash fertilizer which was widely used in agriculture. But $\mathrm{K}^{+}$is easily absorbed by plants. It can lead to the lower content of $\mathrm{K}^{+}$ than that of $\mathrm{SO}_{4}{ }^{2-}$ in groundwater. Meanwhile, the concentration of $\mathrm{SO}_{4}{ }^{2-}$ was also lower than that of major ions in most samples. In PC4 and PC5, $\mathrm{F}^{-}$and $\mathrm{Cl}^{-}$had higher loadings, respectively. But the concentrations of them were low in groundwater. Both ions may originate from the dissolution of minerals containing $\mathrm{F}^{-}$and $\mathrm{Cl}^{-}$. Consequently, PC3, PC4, and PC5 represent the processes that minor ions with lower content than that of major ions in most samples enter groundwater by human activities and water-rock interactions.

Overall, PCA classifies major and minor ions according to their sources.

\subsection{Sources of Main Ions}

The dissolution of carbonate minerals, $\mathrm{Na}-\mathrm{Ca}$ exchange, and the use of nitrogenous fertilizers are the main sources of $\mathrm{Ca}^{2+}, \mathrm{Mg}^{2+}, \mathrm{HCO}_{3}{ }^{-}, \mathrm{Na}^{+}$, and $\mathrm{NO}_{3}{ }^{-}$, according to the previous description. This part will discuss those processes in detail. $\mathrm{Na}-\mathrm{Ca}$ exchange is discussed first for the sake of convenience. 


\subsubsection{Na-Ca Exchange}

$\mathrm{Na}-\mathrm{Ca}$ exchange can change the concentrations of cations in groundwater. It is a significant process in the evolution of hydrochemical compositions [15]. It can be studied by chloro-alkaline indices (CAI-I and CAI-II) which were proposed by Schoeller [28]. The formulas are shown below.

$$
\begin{gathered}
\mathrm{CAI}-\mathrm{I}=\frac{\mathrm{Cl}^{-}-\left(\mathrm{Na}^{+}+\mathrm{K}^{+}\right)}{\mathrm{Cl}^{-}} \\
\mathrm{CAI}-\mathrm{II}=\frac{\mathrm{Cl}^{-}-\left(\mathrm{Na}^{+}+\mathrm{K}^{+}\right)}{\mathrm{HCO}_{3}^{-}+\mathrm{SO}_{4}^{2-}+\mathrm{CO}_{3}^{2-}+\mathrm{NO}_{3}^{-}}
\end{gathered}
$$

The unit of all ions in these two formulas is meq/L. If the values of two indices are negative, it indicates that a certain amount of $\mathrm{Ca}^{2+}$ in groundwater was replaced by a corresponding amount of $\mathrm{Na}^{+}$in soil. If the indices are positive, it indicates that the reaction had happened in the opposite direction. A diagram of chloro-alkaline indices is shown in Figure 3. From it, 86.7\% of fifteen samples were located in the lower left area, indicating that $\mathrm{Na}-\mathrm{Ca}$ exchange is common in the basin. Therefore, Na-Ca exchange is the important source of $\mathrm{Na}^{+}$in the groundwater of the basin. It is consistent with the inferential result of the correlation analysis and PCA.

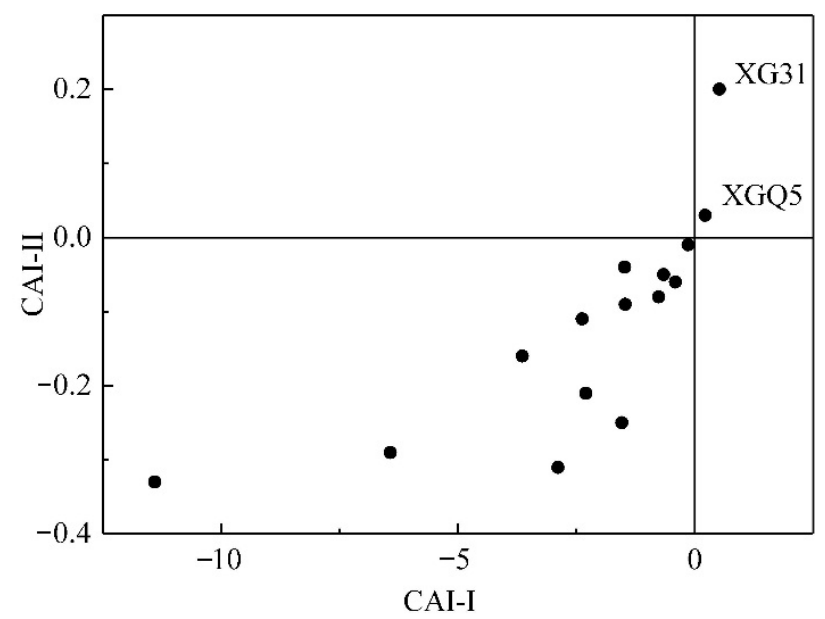

Figure 3. Diagram of chloro-alkaline indices.

\subsubsection{Dissolution of Carbonate Minerals}

The dissolution of carbonate minerals is very common in the groundwater system of northern China [14]. In theory, dissolving one or more kinds of carbonate minerals, such as calcite $\left(\mathrm{CaCO}_{3}\right)$, magnesite $\left(\mathrm{MgCO}_{3}\right)$, or dolomite $\left(\mathrm{CaMg}\left(\mathrm{CO}_{3}\right)_{2}\right)$, will introduce $\mathrm{Ca}^{2+} / \mathrm{Mg}^{2+}$ and $\mathrm{HCO}_{3}{ }^{-}$into groundwater with a proportion from 1:1 to 1:2, which depends on the content of atmospheric $\mathrm{CO}_{2}$ participated in the reactions [14]. The proportion diagrams of those ions are shown in Figure 4. Almost all of the fifteen samples were located below the 1:2 line in the proportional relation between $\mathrm{Ca}^{2+} / \mathrm{Mg}^{2+}$ and $\mathrm{HCO}_{3}{ }^{-}$ (Figure 4a,b). Meanwhile, nearly half of the samples fell out of the range from 1:1 to 1:2 in the proportional relation between $\mathrm{Ca}^{2+}+\mathrm{Mg}^{2+}$ and $\mathrm{HCO}_{3}{ }^{-}$(Figure $4 \mathrm{c}$ ). These results show that the molar concentrations of $\mathrm{Ca}^{2+}, \mathrm{Mg}^{2+}$, and $\mathrm{Ca}^{2+}+\mathrm{Mg}^{2+}$ are less than double that of $\mathrm{HCO}_{3}{ }^{-}$in most samples. If the dissolution of carbonate minerals is really the sources of those ions, there must exist in some other reactions which can affect the content of those ions in groundwater. Na-Ca exchange which can reduce the content of $\mathrm{Ca}^{2+}$ in groundwater is one of those reactions. Previous section has verified that $\mathrm{Na}-\mathrm{Ca}$ exchange is common indeed in the basin. Thus, convert $\mathrm{Na}^{+}$into $\mathrm{Ca}^{2+}$ according to the transformation relation of 2:1 (except for the samples from XG31 and XGQ5), then plot the proportion diagram between $\mathrm{Ca}^{2+}+\mathrm{Mg}^{2+}+0.5 \mathrm{Na}^{+}$and $\mathrm{HCO}_{3}{ }^{-}$(Figure $4 \mathrm{~d}$ ). From it, all samples 
fell into the range from 1:1 to 1:2, suggesting that $\mathrm{Na}-\mathrm{Ca}$ exchange is the cause leading to the abnormal ionic proportional relations. All processes indicate that the dissolution of multiple carbonate minerals, including calcite and magnesite etc., is the main sources of $\mathrm{HCO}_{3}{ }^{-}, \mathrm{Ca}^{2+}$, and $\mathrm{Mg}^{2+}$ in the groundwater of the basin. And it also illustrates indirectly that $\mathrm{Na}^{+}$in the groundwater of the basin mainly originates from $\mathrm{Na}-\mathrm{Ca}$ exchange. These results are consistent with the inferences of the correlation analysis and PCA.
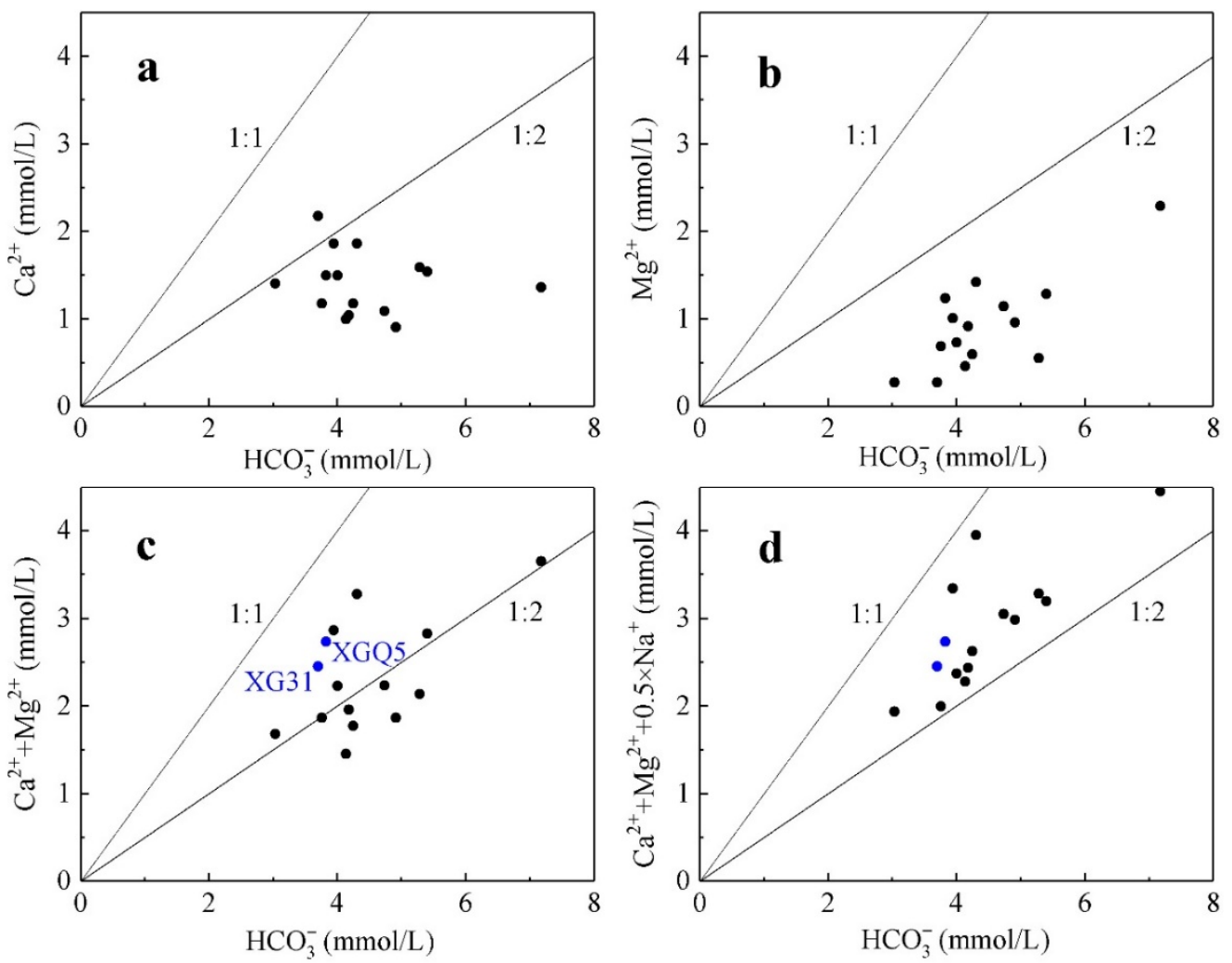

Figure 4. Proportion diagrams of ions.

\subsubsection{Transformation of Organic Nitrogen Fertilizers}

Nitrogen compounds in groundwater usually originate from the use of nitrogen fertilizers in agricultural areas [29]. The most common nitrogen fertilizer is urea. It is a kind of organic nitrogen fertilizer and was widely used in the agriculture of the study area. According to statistic, the average usage of urea was approximately $85 \mathrm{t} / \mathrm{km}^{2}$ [30].The processes of its transformation and migration are as follows. Mineralization occurs with the participation of bacteria in soil after fertilization. It turns organic nitrogen into $\mathrm{NH}_{4}{ }^{+}$. Then nitrification happens with the participation of nitrosobacteria and nitrobacteria. It first transforms $\mathrm{NH}_{4}{ }^{+}$into $\mathrm{NO}_{2}{ }^{-}$, and then transforms $\mathrm{NO}_{2}{ }^{-}$into $\mathrm{NO}_{3}{ }^{-}$. The transformation is over at this time. Those inorganic nitrogen is continually absorbed by crops during the total transformation. But there is also a certain amount of the residual inorganic nitrogen in soil. It can enter shallow groundwater with the infiltration of rainwater or irrigation water through aeration zone. Thus, those nitrogen compounds were observed in the groundwater of the basin.

For $\mathrm{NO}_{3}{ }^{-}$, its content in the groundwater of the basin was higher and more than half of the samples exceeded its standard limit, due to the fact that more than $70 \%$ of the Xinzhou basin is cultivated land. For $\mathrm{NO}_{2}{ }^{-}$, it is an intermediate product and its quantities generated in the transformation are very small. Therefore, its quantities entering groundwater are also small. However, there was a positive correlation between $\mathrm{NO}_{3}{ }^{-}$ and $\mathrm{NO}_{2}{ }^{-}$in groundwater, with the correlation coefficient of 0.524 at the significance level of 0.05 (Table 5), due to $\mathrm{NO}_{2}{ }^{-}$directly involves in the formation of $\mathrm{NO}_{3}{ }^{-}$. For $\mathrm{NH}_{4}{ }^{+}$, 
its amount entering groundwater is very small, because the adsorption of aeration zone results in most $\mathrm{NH}_{4}{ }^{+}$retaining in topsoil [31,32].

\subsection{Formation Mechanisms of Groundwater Chemistry}

Gibbs proposed two semi-logarithmic diagrams to assess the evolution mechanisms of regional groundwater, including precipitation dominance, rock dominance, and evaporation dominance [33]. The vertical coordinates of these two diagrams are logarithmic, both showing TDS; However, the horizontal coordinates of them are linear, showing the values of $\mathrm{Na}^{+} /\left(\mathrm{Na}^{+}+\mathrm{Ca}^{2+}\right)$ and $\mathrm{Cl}^{-} /\left(\mathrm{Cl}^{-}+\mathrm{HCO}_{3}{ }^{-}\right)$, respectively. Gibbs diagrams of the fifteen samples are shown in Figure 5. From it, all samples were located in the area of rock dominance. This illustrates that the weathering of rock minerals is the dominant factor which controls the evolution of the shallow groundwater in the basin. It can also be observed that the values of TDS had no significant changes with the increasing values of $\mathrm{Na}^{+} /\left(\mathrm{Na}^{+}+\mathrm{Ca}^{2+}\right)$, suggesting the influence of $\mathrm{Na}-\mathrm{Ca}$ exchange. The exchange process is that $1 \mathrm{~mol} \mathrm{Ca}^{2+}$ in groundwater is replaced by $2 \mathrm{~mol} \mathrm{Na}^{+}$in soil. It can not change the content of TDS significantly, because the mass of the former $(40 \mathrm{~g} / \mathrm{mol})$ is approximately equal to that of the latter $(23 \times 2=46 \mathrm{~g} / \mathrm{mol})$.
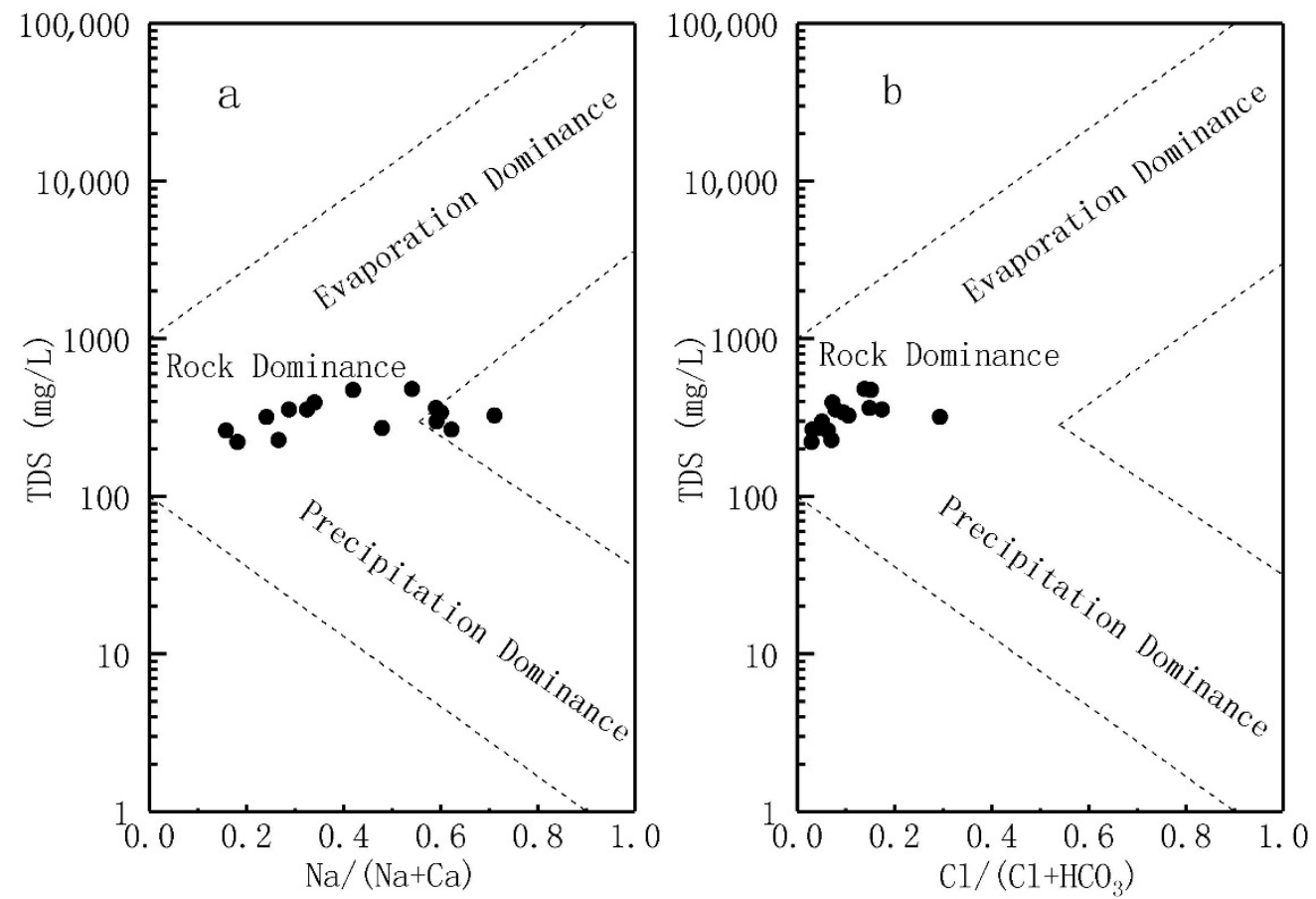

Figure 5. Gibbs diagrams of samples.

\subsection{Water Quality Assessment}

\subsubsection{Irrigation Water Quality Assessment}

The Xinzhou basin is a typical agricultural area where irrigation mainly depends on local shallow groundwater. Thus, groundwater quality directly affects the sustainable development of local agriculture. SAR and \% Na of all samples were calculated in order to evaluate groundwater quality. It was found that SAR of fifteen samples ranged from 0.19 to 1.63 and the maximum of $\% \mathrm{Na}$ was $37.3 \%$, suggesting the probability of sodium hazard is low. However, the values of SAR in two samples from wells XGQ36-1 and XG21 reached to 6.58 and 9.08 respectively, and the values of $\% \mathrm{Na}$ reached to $57.0 \%$ and $67.4 \%$ respectively, indicating the probability of sodium hazard is relatively high.

The US Salinity Laboratory diagram (USSL) and the Wilcox diagram can be used to evaluate the suitability of irrigation water based on alkalinity and salinity [11]. The vertical ordinates of those two diagrams are SAR and \%Na respectively, and the horizontal 
ordinates of them are both electric conductivity (EC). EC can be measured or calculated according to Standard Method 2510-A [34]. Its calculated values were used, because EC was not measured. Plot the two diagrams (Figure 6). It shows that fifteen samples fell into the C2S1 area in the USSL diagram and the area of "Excellent to Good" in the Wilcox diagram, indicating that the groundwater in most areas of the basin is suitable for irrigation. However, two samples from wells XGQ36-1 and XG21 fell into the C4S2 area in the USSL diagram and the area of "Doubtful to Unsuitable" in the Wilcox diagram, suggesting their unsuitability for irrigation. Those wells of XGQ36-1 and XG21 were previously mentioned many times. They are both located in the south of the basin.
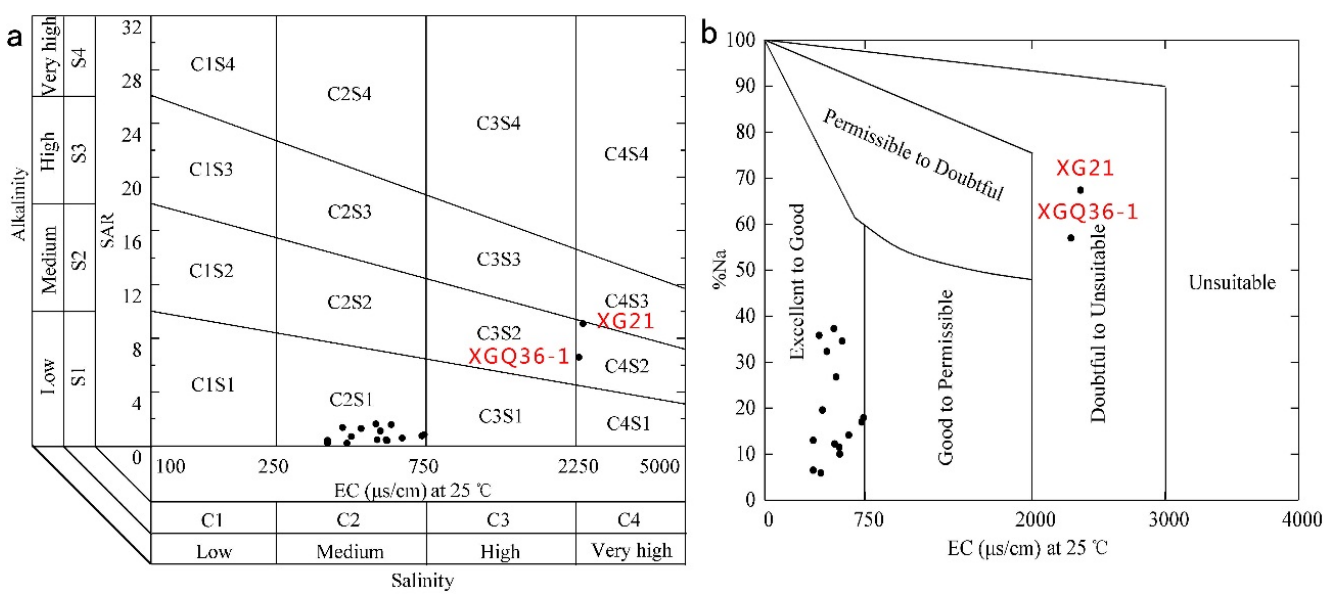

Figure 6. USSL (a) and Wilcox (b) diagrams of samples.

\subsubsection{Drinking Water Quality Assessment}

The results of WQI are shown in Figure 7. From it, WQI generally increased with TDS. Besides, the sample numbers of excellent quality, good quality, poor quality, very poor quality, and unsuitable for any use were five, nine, one, zero, and two, accounting for $29.41 \%, 52.94 \%, 5.88 \%, 0 \%$, and 11.76 respectively. Thus, more than $80 \%$ of samples were excellent or good water quality, suggesting that groundwater in most areas of the basin is suitable for drinking. The spatial distribution of groundwater quality for drinking was drawn (Figure 8), based on the results of WQI model. From it, groundwater in some parts of the southern basin was unsuitable for drinking, including the south, east, and northeast of Dingxiang county, as well as the southwest of Yuanping county.

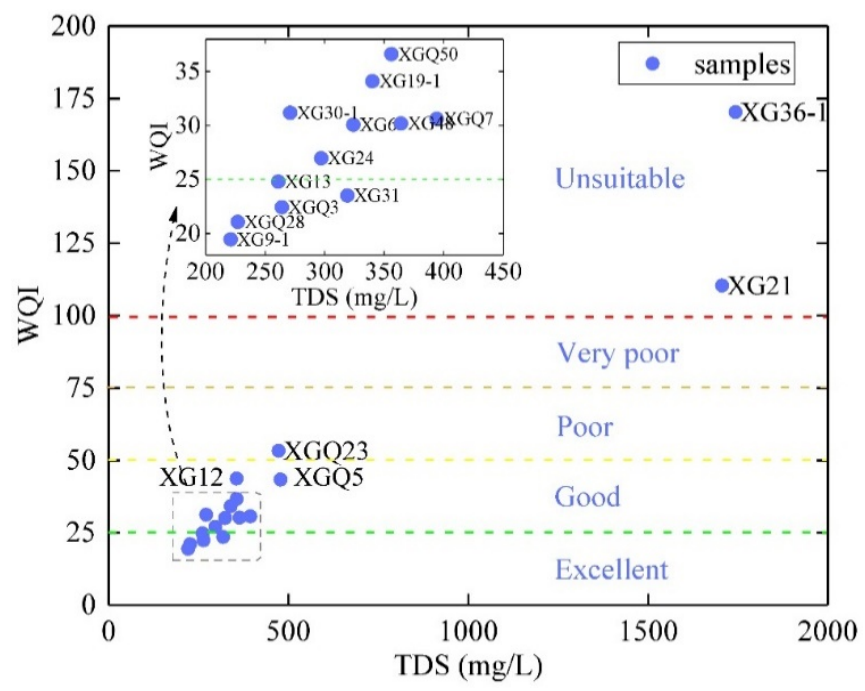

Figure 7. Diagram of groundwater TDS versus WQI. 


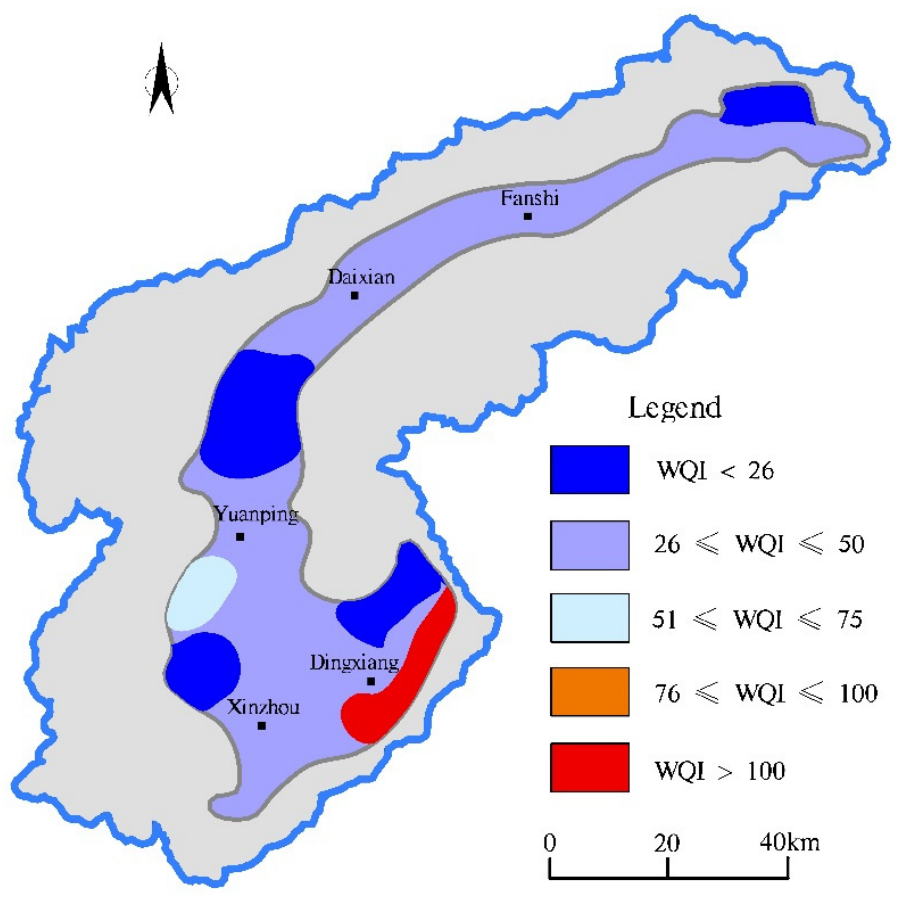

Figure 8. Spatial distribution of water quality index.

In summary, the groundwater in most areas of the basin is suitable for irrigation and drinking. However, its quality is extremely poor in some southern parts of the basin, which leads to its unsuitability for any use. The main reason for the poor water quality in some areas is the influence of human activities, especially the emission of industrial pollutants, according to the previous analysis. Therefore, government should urge enterprises to do well in the harmless disposal of industrial pollutants. Meanwhile, the real-time monitoring and warning system of groundwater quality should be established. Moreover, in recent years, the research and application of quality sensors is increasing. This technology is meaningful to improve the accuracy of real-time monitoring and warning of groundwater quality $[35,36]$. In the end, it is also necessary to formulate a plan to dispose of the contaminated groundwater promptly. Only in this way can groundwater pollution be prevented and controlled.

\section{Conclusions}

Shallow groundwater is an essential resource. It was widely used in the agriculture and resident life of the Xinzhou basin. This research discussed the hydrochemical characteristics and evolution of the shallow groundwater in the basin, with the methods of Piper diagrams, correlation analysis, PCA, chloro-alkaline indices, ion proportion diagrams, and Gibbs diagrams. Meanwhile, using two indicators of SAR and \%Na, USSL and Wilcox diagrams, and WQI models assessed local groundwater quality. The following conclusions can be drawn.

(1) The concentrations of TDS, $\mathrm{TH}, \mathrm{Na}^{+}, \mathrm{SO}_{4}{ }^{2-}, \mathrm{Cl}^{-}, \mathrm{F}^{-}$, and $\mathrm{NO}_{3}{ }^{-}$in some areas of the basin exceeded their standard limits. Nitrate pollution among them was the most extensive and almost occurred in the whole basin. The hydrochemical facies were $\mathrm{HCO}_{3}-\mathrm{Ca}$ and mixed $\mathrm{HCO}_{3}-\mathrm{Ca} \cdot \mathrm{Mg} \cdot \mathrm{Na}$ types in most areas of the basin, but $\mathrm{HCO}_{3} \cdot \mathrm{SO}_{4} \cdot \mathrm{Cl}-\mathrm{Na}$ type in the small parts of the southern basin.

(2) The evolution of the shallow groundwater in the study area was dominated by the weathering of rock minerals, except for the influence of human activities. The main processes of hydrochemistry included the dissolution of carbonate minerals and $\mathrm{Na}-\mathrm{Ca}$ exchange. The former introduced $\mathrm{HCO}_{3}{ }^{-}, \mathrm{Ca}^{2+}$, and $\mathrm{Mg}^{2+}$ into groundwater, and the latter brought $\mathrm{Na}^{+}$into groundwater. 
(3) Nitrate pollution originated from the use of nitrogen fertilizers in agriculture. Organic nitrogen fertilizers were transformed into inorganic nitrogen in aeration zone after fertilization. Then, those inorganic nitrogen was mostly absorbed by crops, and residual parts entered shallow groundwater with the infiltration of rainwater and irrigation water through aeration zone.

(4) Groundwater in most areas of the basin was suitable for irrigation and drinking. However, its quality was poor in some parts of the southern basin. Those areas with poor water quality should be focused on. And groundwater there needs to be treated before irrigation and drinking.

More research should be done, such as the spatial distribution characteristics and migration laws of nitrogen, the rational use of nitrogen fertilizers in large-scale agricultural areas, and developing new fertilizers with low pollution, in view of the general problem of nitrate pollution. Besides, government should urge enterprises to do well in harmless disposal of pollutants, and strictly control the emission of pollutants in local industry areas. Further enhancing the monitoring of groundwater quality is also necessary.

Author Contributions: G.S. collected and analyzed the data, and then wrote the paper; J.S., Y.C., Q.Z. and Y.G. revised the paper. All authors have read and agreed to the published version of the manuscript.

Funding: This research received no external funding.

Data Availability Statement: Data sharing not applicable.

Acknowledgments: The authors thank the water department of Xinzhou city for providing groundwater data.

Conflicts of Interest: The authors declare no conflict of interest.

\section{References}

1. Gu, X.; Zhang, Q.; Cui, Y.; Shao, J.; Xiao, Y.; Zhang, P.; Liu, J. Hydrogeochemistry and Genesis Analysis of Thermal and Mineral Springs in Arxan, Northeastern China. Water 2017, 9, 61. [CrossRef]

2. Hui, T.; Jizhong, D.; Shimin, M.; Zhuang, K.; Yan, G. Application of water quality index and multivariate statistical analysis in the hydrogeochemical assessment of shallow groundwater in Hailun, northeast China. Hum. Ecol. Risk Assess. Int. J. 2021, 27, 651-667. [CrossRef]

3. Xiao, Y.; Shao, J.; Cui, Y.; Zhang, G.; Zhang, Q. Groundwater circulation and hydrogeochemical evolution in Nomhon of Qaidam Basin, northwest China. J. Earth Syst. Sci. 2017, 126, 26. [CrossRef]

4. Zhang, Z.; Wang, Z.; Xu, Y.; Zhang, Y.; Guo, L.; Zheng, Q.; Tang, L. Quantitative Study on the Changes of Karst Groundwater Level and Hydrochemistry in Jinci Spring Catchment, Shanxi, China. Expo. Health 2019, 12, 513-525. [CrossRef]

5. Zheng, Q.; Zhang, Y.; Li, Y.; Zhang, Z.; Wu, A.; Shi, H. Adsorption of sulfate from acid mine drainage in Northwestern China using Malan loess. Arab. J. Geosci. 2019, 12, 348. [CrossRef]

6. Appelo, C.A.J.; Postma, D. Geochemistry, Groundwater and Pollution; CRC Press: Boca Raton, FL, USA, 2004.

7. Adimalla, N.; Wu, J. Groundwater quality and associated health risks in a semi-arid region of south India: Implication to sustainable groundwater management. Hum. Ecol. Risk Assess. Int. J. 2019, 25, 191-216. [CrossRef]

8. Gowing, J.; Walker, D.; Parkin, G.; Forsythe, N.; Haile, A.T.; Ayenew, D.A. Can shallow groundwater sustain small-scale irrigated agriculture in sub-Saharan Africa? Evidence from N-W Ethiopia. Groundw. Sustain. Dev. 2020, 10, 1-11. [CrossRef]

9. Kalhor, K.; Ghasemizadeh, R.; Rajic, L.; Alshawabkeh, A. Assessment of groundwater quality and remediation in karst aquifers: A review. Groundw. Sustain. Dev. 2019, 8, 104-121. [CrossRef] [PubMed]

10. Apollaro, C.; Vespasiano, G.; Muto, F.; De Rosa, R.; Barca, D.; Marini, L. Use of mean residence time of water, flowrate, and equilibrium temperature indicated by water geothermometers to rank geothermal resources. Application to the thermal water circuits of Northern Calabria. J. Volcanol. Geotherm. Res. 2016, 328, 147-158. [CrossRef]

11. Li, P.; Tian, R.; Liu, R. Solute Geochemistry and Multivariate Analysis of Water Quality in the Guohua Phosphorite Mine, Guizhou Province, China. Expo. Health 2018, 11, 81-94. [CrossRef]

12. Wu, J.; Zhang, Y.; Zhou, H. Groundwater chemistry and groundwater quality index incorporating health risk weighting in Dingbian County, Ordos basin of northwest China. Geochemistry 2020, 80, 1-31. [CrossRef]

13. Zhou, Y.; Li, P.; Xue, L.; Dong, Z.; Li, D. Solute geochemistry and groundwater quality for drinking and irrigation purposes: A case study in Xinle City, North China. Geochemistry 2020, 80, 1-37. [CrossRef]

14. Li, P.; Qian, H.; Wu, J.; Zhang, Y.; Zhang, H. Major Ion Chemistry of Shallow Groundwater in the Dongsheng Coalfield, Ordos Basin, China. Mine Water Environ. 2013, 32, 195-206. [CrossRef] 
15. Su, Z.; Wu, J.; He, X.; Elumalai, V. Temporal Changes of Groundwater Quality within the Groundwater Depression Cone and Prediction of Confined Groundwater Salinity Using Grey Markov Model in Yinchuan Area of Northwest China. Expo. Health 2020, 12, 447-468. [CrossRef]

16. Critelli, T.; Marini, L.; Schott, J.; Mavromatis, V.; Apollaro, C.; Rinder, T.; De Rosa, R.; Oelkers, E. Dissolution rates of actinolite and chlorite from a whole-rock experimental study of metabasalt dissolution from $2 \leq \mathrm{pH} \leq 12$ at $25^{\circ} \mathrm{C}$. Chem. Geol. 2014, 390, 100-108. [CrossRef]

17. Palandri, J.L.; Kharaka, Y.K. A Compilation of Rate Parameters of Water-Mineral Interaction Kinetics for Application to Geochemical Modeling; US Geological Survey: Reston, VA, USA, 2004.

18. Han, D.; Liang, X.; Currell, M.J.; Song, X.; Chen, Z.; Jin, M.; Liu, C.; Han, Y. Environmental isotopic and hydrochemical characteristics of groundwater systems in Daying and Qicun geothermal fields, Xinzhou Basin, Shanxi, China. Hydrol. Process. 2010, 24, 3157-3176. [CrossRef]

19. Han, D.; Liang, X.; Jin, M.; Currell, M.J.; Han, Y.; Song, X. Hydrogeochemical Indicators of Groundwater Flow Systems in the Yangwu River Alluvial Fan, Xinzhou Basin, Shanxi, China. Environ. Manag. 2009, 44, 243-255. [CrossRef]

20. Han, D.; Liang, X.; Jin, M.; Currell, M.; Song, X.; Liu, C. Evaluation of groundwater hydrochemical characteristics and mixing behavior in the Daying and Qicun geothermal systems, Xinzhou Basin. J. Volcanol. Geotherm. Res. 2010, 189, 92-104. [CrossRef]

21. Sun, J. Study on the Geothermal System and the Hydrogeochemical Modeling in the Xinzhou Basin of Shanxi Province. Master's Thesis, China University of Geosciences (Beijing), Beijing, China, 2006. (In Chinese)

22. Zhang, X. Study of the Groundwater System and the Hydrogeochemical Modeling in the Qicun Geothermal Field. Master's Thesis, China University of Geosciences (Beijing), Beijing, China, 2005. (In Chinese)

23. Hem, J.D. Study and Interpretation of the Chemical Characteristics of Natural Waters, 3rd ed.; Scientific: Jodhpur, India, 1991.

24. Meng, Q.; Zhang, J.; Zhang, Z.; Wu, T. Geochemistry of dissolved trace elements and heavy metals in the Dan River Drainage (China): Distribution, sources, and water quality assessment. Environ. Sci. Pollut. Res. 2016, 23, 8091-8103. [CrossRef] [PubMed]

25. WHO. Guidelines for Drinking-Water Quality, 4th ed.; World Health Organization: Geneva, Switzerland, 2017.

26. GB/T 14848-2017. Standards for Groundwater Quality; China Standards Press: Beijing, China, 2017. (In Chinese)

27. Lucas, L.; Jauzein, M. Use of principal component analysis to profile temporal and spatial variations of chlorinated solvent concentration in groundwater. Environ. Pollut. 2008, 151, 205-212. [CrossRef]

28. Schoeller, H. Qualitative evaluation of ground water resources. In Methods and Techniques of Groundwater Investigation and Development; Schoeller, H., Ed.; UNESCO: Paris, France, 1967; Volume 33, pp. 44-52.

29. Devic, G.; Đorđević, D.; Sakan, S. Natural and anthropogenic factors affecting the groundwater quality in Serbia. Sci. Total. Environ. 2014, 468-469, 933-942. [CrossRef]

30. Fan, X. Problems and countermeasures of replacing chemical fertilizer with organic fertilizer. Agri. Technol. Equip. 2018, 339, 21-23. (In Chinese)

31. Michal, K.; Miroslava, N.; Eva, H.; Kriska, M.; Nemcova, M.; Hyánková, E. The influence of ammonia on groundwater quality during wastewater irrigation. Soil Water Res. 2018, 13, 161-169. [CrossRef]

32. Saha, B.K.; Rose, M.T.; Wong, V.N.L.; Cavagnaro, T.R.; Patti, A.F. Nitrogen Dynamics in Soil Fertilized with Slow Release Brown Coal-Urea Fertilizers. Sci. Rep. 2018, 8, 14577. [CrossRef] [PubMed]

33. Gibbs, R.J. Mechanisms Controlling World Water Chemistry. Science 1970, 170, 1088-1090. [CrossRef]

34. APHA. Standard Methods for the Examination of Water and Wastewater, 19th ed.; American Public Health Association: Washington, DC, USA, 1995.

35. Yaroshenko, I.; Kirsanov, D.; Marjanovic, M.; Lieberzeit, P.A.; Korostynska, O.; Mason, A.; Frau, I.; Legin, A. Real-Time Water Quality Monitoring with Chemical Sensors. Sensors 2020, 20, 3432. [CrossRef] [PubMed]

36. Sambito, M.; Freni, G. Strategies for Improving Optimal Positioning of Quality Sensors in Urban Drainage Systems for NonConservative Contaminants. Water 2021, 13, 934. [CrossRef] 